\title{
PENYULUHAN HUKUM DALAM UPAYA MENINGKATKAN PARTISIPASI MASYARAKAT DALAM PEMILIHAN KEPALA DESA SERENTAK DI KABUPATEN CIAMIS
}

\section{LEGAL EXPLANATION IN AN EFFORT TO INCREASE COMMUNITY PARTICIPATION IN THE ELECTION OF AVILLAGE HEAD IN CIAMIS DISTRICT}

\author{
Taopik Iskandar*, Dewi Mulyanti \\ Fakultas Hukum Universitas Galuh \\ J1. R. E. Martadinata No.150 Ciamis 46274 \\ *Email: taopika@gmail.com \\ (Diterima 02-09-2021; Disetujui 24-09-2021)
}

\begin{abstract}
ABSTRAK
Mitra dalam kegiatan ini adalah Panitia Pemilihan Kepala Desa Pusakanagara. Permasalahan yang dialami oleh mitra adalah menurunnya animo masyarakat dalam pemilihan kepala desa dikarenakan terjadinya penundaan pelaksaan pencoblosan yang mengakibatkan ketidakpastian pelaksanaanya di masa pandemi covid19, sehingga dimungkinkan dapat menyebabkan tidak tercapainya jumlah pemilih yang diharapkan. Solusi yang ditawarkan dalam menghadapi permasalahan mitra adalah: Penyuluhan Hukum dan Pendampingan. Kegiatan pengabdian ini memiliki tujuan untuk memberikan pemahaman akan pentingnya berpartisipasi dalam pemilihan kepala desa serentak agar terwujudnya sistem demokrasi dengan asas langsung, umum, bebas, rahasia, jujur, dan adil; dan tingginya angka keterlibatan pemilih dalam menggunakan hak pilihnya.
\end{abstract}

Kata Kunci : Penyuluhan hukum, Partisipasi Masyarakat, Pemilihan, Kepala Desa

\section{ABSTRACT}

Partner in this activity is the Pusakanagara Village Head Election Committee. The problem experienced by partners is the decline in community interest in village head elections due to delays in the implementation of the voting which results in uncertainty in its implementation during the covid-19 pandemic, so it is possible that it can cause the expected vote not to be achieved. The solutions offered in dealing with partner problems are: Legal Counseling and Assistance. This service activity has the aim of providing an understanding of the importance of participating in simultaneous village head elections in order to realize a democratic system with direct, general, free, confidential, honest and fair principles and a high number of voter involvement in exercising their voting rights.

Keywords: Legal Counseling, Community Participation, Election, Village Head

\section{PENDAHULUAN}

Konsep demokrasi dapat diartikan sebagai suatu pemerintahan yang berasal dari rakyat, oleh rakyat dan untuk rakyat, karenanya salah satu pilar demokrasi adalah partisipasi politik. Partisipasi politik merupakan bentuk keikutsertaan warga dalam proses politik, dalam negara demokrasi rakyat diharapkan dapat ikut berpartisipasi politik secara aktif. Partisipasi aktif warga negara dapat dilaksanakan dalam berbagai bentuk, salah satunya adalah dengan ikut serta dalam pemilihan pemimpin pemerintah, termasuk pemilihan kepala desa, sebagaimana tercantum dalam Peraturan Menteri Dalam Negeri Nomor 112 Tahun 2014 tentang Pemilihan Kepala Desa sebagaimana telah diubah dengan Peraturan Menteri Dalam Negeri Nomor 65 Tahun 2017 tentang Perubahan Atas Peraturan 
Penyuluhan Hukum Dalam Upaya Meningkatkan Partisipasi Masyarakat Dalam Pemilihan Kepala Desa Serentak di Kabupaten Ciamis

Taopik Iskandar, Dewi Mulyanti

Menteri Dalam Negeri Nomor 112 Tahun 2014 tentang Pemilihan Kepala Desa dinyatakan bahwa pemilihan kepala desa adalah pelaksanaan kedaulatan rakyat di desa dalam rangka memilih kepala desa yang bersifat langsung, umum, bebas, rahasia, jujur, dan adil. Hal ini untuk secara langsung atau tidak langsung mempengaruhi kebijakan pemerintah (public policy).

Pelaksanaan pilkades serentak gelombang ke-3 di Kabupaten Ciamis sebagaimana tercantum dalam Keputusan Bupati Ciamis Nomor 141.1/Kpts.426-Huk/2019 tentang Tahapan Pemilihan Kepala Desa Serentak Tahun 2020 di Kabupaten Ciamis dilaksanakan tanggal 12 April 2020 yang diikuti oleh 143 desa di 27 kecamatan. Akan tetapi, pada bulan April terjadi pandemi covid 19 maka pelaksanaannya ditangguhkan menjadi tanggal 15 Agustus 2020, dan diundur lagi menjadi tanggal 19 Desember 2020.

Dengan sejalannya perubahan jadwal pelaksanaan pemilihan kepala desa, hal ini sedikit banyak dapat mempengaruhi terhadap antusiasme masyarakat ataupun para calon kepala desa itu sendiri sehingga dikhawatirkan terjadi penurunan partisipasi masyarakat dalam pemilihan kepala desa di Desa Pusakanagara. Dalam Perda No. 7 Tahun 2015 Tentang Pemilihan, Pengangkatan dan Pemberhentian Kepala Desa Pasal 52 ayat (2) dinyatakan bahwa pemilihan dinyatakan sah apabila pemilih yang menggunakan hak pilih berjumlah paling sedikit 50\% (lima puluh per seratus) ditambah 1 (satu) dari jumlah pemilih di desa setempat. Berdasarkan analisis situasi di atas, maka dapat dikemukakan beberapa permasalahan, sebagai berikut: Terjadinya penurunan partisipasi masyarakat terhadap pemilihan kepala Desa akibat masa pandemi covid 19 dan kepastian jadwal pelaksanaan pemilihan kepala desa? Bagaimanakah strategi untuk meningkatkan partisipasi masayarakat dalam pemilihan kepala desa di Desa Pusakanagara?

Berdasarkan masalah terkait dengan tema kegiatan yang telah dirumuskan di atas, maka yang menjadi tujuan kegiatan pengabdian ini adalah sebagai berikut: Memberikan pemahaman kepada masyarakat dan memperluas wawasan tentang pentingnya partisipasi masayarakat dalam pemilihan kepala desa yaitu dengan melakukan pemungutan suara pada waktu yang telah ditentukan dalam tahapan pelaksanaan pemungutan suara, dan memberikan masukan tentang strategi untuk meningkatkan partisipasi masayarakat dalam pemilihan kepala desa di Desa Pusakanagara. Adapun manfaat dari kegiatan ini diharapkan dapat membantu masyarakat Desa Pusakanagara dalam memahami dan membantu panitia pemilihan untuk meningkatkan partisipasi masyarakat dalam pemilihan kepala desa sehingga proses demokratisasi dapat terwujud sesuai dengan asas pemilihan, yaitu langsung, umum, bebas, rahasia, jujur dan adil; serta berkepastian hokum. 


\section{BAHAN DAN METODE PELAKSANAAN}

Setiap negara memiliki corak demokrasi yang tercermin pada pola sikap, keyakinan dan perasaan tertentu yang mendasari dan memberi arti pada tingkah laku dan proses berdemokrasi serta mempunyai ciri khas dalam pelaksanaan kedaulatan rakyat atau demokrasinya yang tidak lepas dari sejarah, kebudayaan, pandangan hidup dan tujuan yang diinginkannya.

Secara etimologis, demokrasi berasal dari bahasa Yunani Kuno, yakni demos dan kratein. Dalam “The Advanced Learner's Dictionary of Current English (Hornby dkk, 1988) dikemukakan bahwa yang dimaksud dengan democracy adalah:(1) country with principles of government in which all adult citizens share through their elected representatives; (2) country with government which encourages and allows rights of citizenship such as freedom of speech, religion, opinion, and association, the assertion of rule of law, majority rule, accompanied by respect for the rights of minorities. (3) society in which there is treatment of each other by citizens as equals. Dari kutipan pengertian tersebut tampak bahwa kata demokrasi merujuk kepada konsep kehidupan negara atau masyarakat dimana warganegara dewasa turut berpartisipasi dalam pemerintahan melalui wakilnya yang dipilih; pemerintahannya mendorong dan menjamin kemerdekaan berbicara, beragama, berpendapat, berserikat, menegakkan rule of law", adanya pemerintahan mayoritas yang menghormati hak-hak kelompok minoritas; dan masyarakat yang warga negaranya saling memberi perlakuan yang sama. ${ }^{1}$

Demokrasi di Indonesia telah dirumuskan dalam UUD Negara Republik Indonesia Tahun 1945 Pasal 1 ayat (2): "kedaulatan berada di tangan rakyat, dan dilaksanakan menurut Undang-Undang Dasar”. Demokrasi Pancasila ialah kerakyatan yang dipimpin oleh hikmat kebijaksanaan dalam permusyawaratan perwakilan, yang merupakan sila keempat dari dasar Negara Pancasila seperti yang tercantum dalam alenia keempat Pembukaan UUD 1945. Penerapan demokrasi Pancasila harus dijiwai oleh sila-sila Ketuhanan. $^{2}$

Secara bahasa (etimologis), demokrasi adalah pemerintahan rakyat banyak. Dalam pengertian peristilahan (terminologis), Abraham Lincoln (1808-1865) Presiden Amerika Serikat yang ke-16 mengatakan bahwa democracy is goverment of the people, by the people and for the people atau "demokrasi adalah pemerintahan dari rakyat, oleh rakyat,

\footnotetext{
${ }^{1}$ Direktorat Jenderal Pembelajaran dan Kemahasiswaan Kementerian Riset, Teknologi, dan Pendidikan Tinggi Republik Indonesia, Pendidikan Kewarganegaraan, 2016, hal 147

${ }^{2}$ C.S.T Kansil dan Christine S.T. Kansil, Ilmu Negara, Jakarta: PT. Pradya Paramita, 2001. Hal 129
} 
Penyuluhan Hukum Dalam Upaya Meningkatkan Partisipasi Masyarakat Dalam Pemilihan Kepala Desa Serentak di Kabupaten Ciamis

Taopik Iskandar, Dewi Mulyanti

dan untuk rakyat”. Karena itu, pemerintahan dikatakan demokratis, jika kekuasaan negara berada di tangan rakyat dan segala tindakan negara ditentukan oleh kehendak rakyat. ${ }^{3}$ Dalam kalimat Schumpeter, "metode demokrasi adalah penataan kelembagaan untuk sampai pada keputusan politik dimana individu meraih kekuasaan untuk mengambil keputusan melalui perjuangan kompetitif untuk meraih juara". 4

Demokrasi kekinian adalah demokrasi yang mampu meningkatkan partisipasi politik masyarakat, sehingga mampu menjadi jawaban terhadap setiap masalah-masalah kebangsaan hari ini. Seperti halnya pemilihan umum baik pemilihan kepala daerah ataupun pemilihan presiden, seharusnya menjadi momen penting untuk menjalankan setiap sendisendi demokrasi, karena demokrasi bagi bangsa Indonesia merupakan tatanan kenegaraan yang paling sesuai dengan martabat manusia yang menghormati dan menjamin pemenuhan hak asasi manusia (HAM). Partisipasi politik merupakan inti dari demokrasi. Demokratis tidaknya suatu sistem politik, ditentukan oleh ada-tidaknya atau tinggi-rendahnya tingkat partisipasi politik warganya. Standar minimal demokrasi biasanya adalah adanya pemilu reguler yang bebas untuk menjamin terjadinya rotasi pemegang kendali negara tanpa adanya penyingkiran terhadap suatu kelompok politik manapun, adanya partisipasi aktif dari warga negara dalam pemilu itu dan dalam proses penentuan kebijakan, terjaminnya pelaksanaan hak asasi manusia yang memberikan kebebasan bagi para warga negara untuk mengorganisasi diri dalam organisasi sipil yang bebas atau dalam partai politik, dan mengekspresikan pendapat dalam forum-forum publik maupun media massa. ${ }^{5}$

Metode kegiatan pelaksanaan program pengabdian pada masyarakat dilakukan dengan memberikan pengetahuan dan pemahaman tentang demokrasi, pemilih dan hak memilih serta proses pemilihan dalam penyelenggaraan pemilihan kepala desa dengan bentuk cerama, tanya jawab dan diskusi.

\section{Ceramah}

Berupa sosialisassi dengan menggunakan metode ceramah kepada tokoh masyarakat, Ketua RW, BPD dan ibu-ibu posyandu sebagai agen sosialisasi untuk menepuktularkan kepada masyarakat tentang demokrasi, pemilih dan hak memilih serta proses pemilihan dalam penyelenggaraan pemilihan kepala desa, terutama mengenai peningkatan partisipasi

\footnotetext{
${ }^{3}$ Deddy Ismatullah dan Asep A. Sahid Gatara, Ilmu Negara dalam Multi Perspektif, Bandung: Pustaka Setia, 2007, hlm 119

${ }^{4}$ Georg Shorensen, Proses dan Prospek dalam Sebuah Dunia yang Sedang berubah, Ctk. Pertama, Yogyakarta: Pustaka Pelajar, 2003, hlm 14

${ }^{5}$ Andi yuliani. www. jdih.sukabumikab.go.id/v1/artikel/detail/5/hak-konstitusional-warga-negara. Di unduh tanggal 21 April 2021
} 
masyarakat dalam upaya mensukseskan penyelenggaraan pemilihan kepala desa di desa Pusakanagara.

\section{Tanya Jawab dan diskusi}

Metode tanya jawab dan diskusi dilakukan untuk mengukur dan menggali persoalan yang berhubungan dengan materi ceramah, serta untuk menggali dan memberikan masukan terhadap masalah-masalah dan kendala-kendala yang sudah, sedang dan kemungkinan terjadi permasalahan terutama berkaitan peningkatan partisipasi pemilih dalam proses pemilihan kepala desa di Desa Pusakanagara.

\section{Pendampingan}

Pendampingan dilakukan dalam program pengabdian pada masyarakat sebagai implementasi dalam kegiatan ceramah dan tanya jawab serta diskusi. Pendampingan bekerjasama dengan peserta penyuluhan untuk memberikan informasi tentang pemilihan kepala desa terutama mengenai informasi agar pemilik hak pilih agar menggunakan hak pilihnya pada hari yang sudah ditentukan.

Pemecahan terhadap masalah kekhawatiran mengenai penurunan partisipasi masyarakat dalam menggunakan hak pilihnya dalam pemilihan kepala desa di Desa Pusakanagara akibat masa pandemi covid 19 dan kepastian jadwal pelaksanaan pemilihan kepala desa. Serta strategi untuk meningkatkan partisipasi masayarakat dalam pemilihan kepala desa di desa Pusakanagara yang dilakukan dengan:

1. Penyuluhan Hukum dalam upaya meningkatkan partisipasi masyarakat dalam pemilihan kepala desa serentak di kabupaten Ciamis.

2. Pendampingan dalam mensosialisasikan jadwal pemilihan

Selanjutnya, mengenai kerangka pemecahan masalah yang telah dirumuskan kemudian direalisasikan oleh tim pengabdi. Pelaksanaan dalam merealisasikan pemecahan masalah tersebut diuraikan sebagaimana terlihat pada Tabel 1.

Tabel 1. Realisasi Pemecahan Masalah

\begin{tabular}{clc}
\hline No. & \multicolumn{1}{c}{ Kegiatan } & \multicolumn{1}{c}{ Pelaksanaan } \\
\hline 1. & $\begin{array}{l}\text { Penyuluhan Hukum 1. } \\
\text { partisipasi masyarakat dalam pemilihan kepala desa serentak di kabupaten }\end{array}$ & Penuluan Hukum dalam upaya meningkatkan \\
& $\begin{array}{l}\text { Ciamis. } \\
\text { 2. }\end{array}$ & $\begin{array}{l}\text { Pendampingan dalam mensosilisasikan jadwal tahapan dan hari pemungutan } \\
\text { suara pemilihan kepala desa }\end{array}$ \\
\hline
\end{tabular}

Pada tanggal 17 Desember 2020 dilakukan program pengabdian pada masyarakat, kegiatan yang dilakukan adalah pemberian pengetahuan hukum melalui penyuluhan hukum yang memberikan pemahaman dan pengetahuan mengenai demokrasi, pemilih dan hak memilih serta proses pemilihan dalam penyelenggaraan pemilihan kepala desa dan 
Penyuluhan Hukum Dalam Upaya Meningkatkan Partisipasi Masyarakat Dalam Pemilihan Kepala Desa Serentak di Kabupaten Ciamis

Taopik Iskandar, Dewi Mulyanti

yang terpenting diberikannya materi mengenai strategi untuk meningkatkan partisipasi pemilih yaitu dengan cara:

1. Membangun kepercayaan (trust) masyarakat bahwa panitia pemilihan telah mempersiapkan TPS dengan standar protokol kesehatan sehingga masyarakat bisa merasa aman datang ke TPS;

2. Memanfaatkan proses sosialisasi melalui digital;

3. Melakukan pengumuman bekerjasama dengan dewan masjid untuk mengajak dan menyampaikan informasi mengenai hari pemungutan suara;

4. Melakukan pengumuman dengan mobil keliling.

Pada tanggal 18 Desember 2020 tim pengabdi melakukan pendampingan dalam proses sosialisasi terhadap masyarakat yang dilakukan oleh peserta penyuluhan yang merupakan pengimplementasian dari hasil penyuluhan, yaitu sosialisasi yang dilakukan oleh kader posyandu terhadap ibu-ibu, sosialisasi melalui mobil keliling oleh panitia, dan informasi melalui pemberian pengumuman sebelum kutbah jumat di masjid oleh tokoh masyarakat.

Khalayak yang menjadi sasaran dalam dalam kegiatan ini adalah masyarakat yang mempunyai hak pilih dalam pemilihan kepala desa di Desa Pusakanagara, namun mengingat jumlah sasaran yang begitu banyak dan waktu yang sangat terbatas, maka tim mengunakan strategi penyuluhan bekerja sama dengan panitia pemilihan kepala desa di Desa Pusakanagara terhadap tokoh masyarakat, ketua RW, BPD dan ibu-ibu posyandu yang nantinya peserta penyuluhan ini menyebarkan langsung terhadap masyarakat.

\section{HASIL DAN PEMBAHASAN}

\section{Hasil Pelaksanaan Kegiatan}

Hasil pelaksanaan kegiatan pengabdian pada masyarakat berupa penyuluhan hukum dan pendampingan terhadap masyarakat terutama tokoh masyarakat, ketua RW, BPD dan kader posyandu di Desa Pusakanagara Kecamatan Baregbeg Kabupaten Ciamis dalam rangka mengimplementasikan Peraturan Menteri Dalam Negeri Republik Indonesia Nomor 112 Tahun 2014 Tentang Pemilihan Kepala Desa dan Peraturan Daerah Kabupaten Ciamis Nomor 7 Tahun 2015 Tentang Pemilihan, Pengangkatan Dan Pemberhentian Kepala Desa yang diawali dengan adanya pertemuan tatap muka melalui metode ceramah berupa pemaparan materi.

Kegiatan pengabdian dilanjutkan dengan pendampingan dalam sosialisasi yang dilakukan peserta penyuluhan dengan kebiasaan dan kegiatan aktifitasnya masing-masing. 
Kader posyandu memberikan sosialisasi terhadap ibu-ibu dalam kegiatan psoyandu, BPD dan pemerintah desa melakukan sosialisasi dalam setiap kegiatan rapat-rapat ataupun pertemuan lainnya, ketua RW dan tokoh masyarakat memberikan sosialisasi langsung kepada masyarakat dalam kegiatan setelah beribadah dan bekerjasama dengan MUI dalam memberikan informasi mengenai hari pencoblosan agar semua pemilik hak pilih agar mengunakan hak pilihnya sebelum pelaksanaan kutbah jumat.

Dalam strategi sosialisasi di lapangan lebih menekankan agar masyarakat yang memiliki hak pilihnya agar hadir ke TPS untuk mencoblos dan tidak usah hawatir dengan pandemi copid 19 karena Panitia Pemilihan telah melakukan perencanaan matang dalam mempersiapkan TPS dan pelaksanaanya dengan menggunakan dan menyediakan perlengkapan protokol kesehatan secara lengkap.

Memberikan pemahaman mengenai pasal 52 ayat (4) Perda no 7 tahun 2015 Tentang Pemilihan, Pengangkatan dan Pemberhentian Kepala Desa dinyatakan bahwa pemilihan dinyatakan sah apabila pemilih yang menggunakan hak pilih berjumlah paling sedikit $50 \%$ (lima puluh per seratus) ditambah 1 (satu) dari jumlah pemilih di desa setempat. Sehingga masyarakat mau datang ke TPS untuk menggunakan hak pilihnya supaya pelaksanan pemilihan berjalan lancer dan membuahkan hasil yang diharapkan.

\section{Pelaksanaan kegiatan Pemilihan Kepala Desa di Desa Pusakanagara}

1. Pelaksanan pemungutan suara

Pelaksanaan pemilihan kepala desa di Desa Pusakanagara Kecamatan Baregbeg dilaksanakan pada hari sabtu tanggal 19 Desember 2020 dimulai pukul 07,00 wib sampai dengan 13.00 wib secara serentak di 6 TPS. Pelaksanan pencoblosan dilaksanakan dengan menjaga protokol kesehatan dengan ketat dimulai dari penjadwalan waktu kehadiran untuk mencoblos dalam undangan pemilih, melakukan cek suhu dengan termogun, mencuci tangan sebelum masuk TPS, diberikan sarung tangan plastik pada setiap pemilih, pengaturan jarak pada waktu tunggu di dalam TPS, dan tidak lupa pemilih untuk menggunakan masker.

2. Penghitungan suara hasil pencoblosan

Penghitungan suara dilakukan pada masing-masing TPS yang dimulai pukul 13.00 sampai dengan selesai.

3. Rekapitulasi hasil penghitungan di Desa

Rekapitulasi hasil penghitungan suara pada masing-masing TPS di lakukan di desa yang dimulai pada pukul 20.00 wib. Berdasarkan Berita Acara Rekapitulasi Penghitungan Surat Suara Sah diperoleh hasil: 
Penyuluhan Hukum Dalam Upaya Meningkatkan Partisipasi Masyarakat Dalam Pemilihan Kepala Desa Serentak di Kabupaten Ciamis

Taopik Iskandar, Dewi Mulyanti

1. Jumlah Surat Suara yang masuk adalah 1.896 suara

a. Suara Sah : 1.860 suara

b. Suara Tidak Sah : :27 suara

c. Suara Blanko :9 suara

2. Perolehan suara sah

a. Nomor urut 1 Sdr Wawan Gani Pratono : 510 suara

b. Nomor urut 2 Sdr Asep Rismayadi, S. Pd : : 1.097 suara

c. Nomor urut 3 Sdr Fauzyana, S.E : 142 suara

d. Nomor urut 4 Sdr Pirman Wardana : 111 suara

3. Suara terbanyak diperoleh Sdr. Asep Rismayadi, S.Pd sebanyak 1.097 suara

Berdasarkan laporan hasil pemilihan kepala desa di desa pusakanagara dinyatakan bahwa:

a. Berdasarkan keputusan panitia pemilihan No. 10 Tahun 2020 Tentang Daftar Pemilih Tetap Daftar Pmilih Tetap diperoleh hasil Jumlah Daftar Pemilih Tetap (DPT) 2.300 orang dengan jumlah laki-laki sebanyak 1.182 orang dan perempuan sebanyak 1.118 orang

b. Jumlah pemilih yang terdaftar dalam DPT ditambah dari DPTb (KTP/keterangan domisili) adalah 2.306 terdiri atas laki-laki 1.183 orang dan perempuan 1.123.

c. Pemilih yang menggunakan hak pilih sebanyak 1.896 orang.

d. Sehingga pemilih yang hadir dan meberikan suaranya apabila diprosentasikan terdapat $82 \%$ partisipasi pemilih dalam menggunakan hak pilihnya; dan ini berarti lebih dari $50 \%$ plus 1 yang hadir maka proses pemilihan ini memenuhi syarat dan bisa dinyatakan sah.

\section{Pembahasan Hasil Pelaksanaan Kegiatan}

Kegiatan pengabdian pada masyarakat dalam upaya meningkatnya partisipasi masyarakat dalam pemilihan kepala desa pada dasarnya mencakup berbagai aspek yang merupakan indikator utama sebagai tolok ukur keberhasilan, yaitu:

1. Target utama jumlah peserta mengikuti pemaparan materi dalam kegiatan penyuluhan hokum.

2. Keberhasilan peserta dalam memahami setiap materi yang disampaikan.

3. Meningkatnya atau banyaknya partisipasi masyarakat yang menggunakan hak pilih dalam pemilihan kepala desa di Desa Pusakanagara Kecamatan Baregbeg Kabupaten Ciamis. 
Dari apa yang telah direncanakan dari target peserta yang mengikuti penyuluhan hukum ini yaitu dari unsur panitia, pemerintahan desa, RW, tokoh masyarakat dan ibu-ibu kader posyandu. Peserta ini merupakan orang-orang yang selalu berhubungan dengan masyarakat secara langsung dan didengar serta dipercaya yang diharapkan dapat menyampaikan atau menularkan pemahaman yang didapat kepada masyarakat.

Dengan melihat jumlah dan pemenuhan unsur-unsur yang hadir dalam acara penyuluhan hukum dari mulai panitia, perangkat desa, BPD, RW, tokoh masyarakat dan kader posyandu maka sesuai seperti yang telah direncanakan.

Mengenai peningkatan pemahaman masyarakat terhadap materi yang disampaikan dalam penyuluhan hukum, maka hal ini dapat dilihat dari respon peserta terhadap pelaksanaan tanya jawab dan diskusi peserta. Namun, jauh lebih penting yaitu bagaiman peserta dapat mengimplementasikan strategi untuk peningkatan patisipasi masyarakat sesuai kegiatan masing-masing.

Mengenai peningkatan ataupun jumlah pastisipasi pemilih dalam menggunakan hak pilihnya di TPS dapat dilihat dari hasil laporan panitia dimana jumlah partisipasi masyarakat mencapi $82 \%$; hal ini berarti kekhawatiran adanya penurunan atau jumlah pemilih sedikit yang diakibatkan oleh pandemi covid-19 dan ketidakpastian jadwal pelaksanaan pemungutan suara hal ini dapat diatasi karena kerja keras dari semua elemen yang menginginkan pelaksanaan pemilihan kepala desa bisa berjalan baik, aman dan lancar.

\section{KESIMPULAN DAN SARAN}

\section{Kesimpulan}

Pelaksanaan program pengabdian pada masyarakat mengenai penyuluhan hukum dalam upaya peningkatan partisipasi masyarakat dalam pemilihan kepala desa dengan materi demokrasi, hak pilih dan proses pemilihan kepala desa dengan menitikberatkan pada strategi untuk meningkatkan partisipasi masyarakat agar datang ke TPS untuk menggunakan hak pilihnya.

Kegiatan pengabdian ini telah berjalan dengan baik dengan tercapainya indikator yang telah ditetapkan, yaitu dari jumlah peserta dengan perwakilan dari unsur panitia, pemerintahan desa, RW, tokoh masyarakat dan ibu-ibu kader posyandu. Pemahaman dan mau menjalankan strategi yang disampaikan dengan melaksanakan sosialisasi langsung kepada masyarakat dengan kegiatan masing-masing. Jumlah partisipasi masyarakat dalam menggunakan hak pilihnya dengan datang langsung ke TPS dengan menjalankan protokol 
Penyuluhan Hukum Dalam Upaya Meningkatkan Partisipasi Masyarakat Dalam Pemilihan Kepala Desa Serentak di Kabupaten Ciamis

Taopik Iskandar, Dewi Mulyanti

kesehatan yang baik mencapai $82 \%$ hal ini merupakan prestasi dari semua unsur masyarakat yang bekerja keras untuk terselenggaranya pemilihan kepala desa di Desa Pusakanagara Kecamatan Baregbeg Kabupaten Ciamis bisa berjalan dengan baik, aman dan lancar.

\section{Saran}

Berdasarkan hasil evaluasi mengenai program pengabdian yang telah dilaskanakan dapat disampakan beberapa saran sebagai berikut:

1. Perlu adanya data kependudukan yang terus dimutahirkan di lingkup desa secara berkelanjutan supaya dapat diketahui dan memudahkan dalam proses pembinaan dan pendidikan terutama terhadap pemilih pemula.

2. Perlu adanya regenerasi dalam penyelenggaraan pemilihan supaya pemahaman tentang hak memilih dan dipilih bisa lebih meluas di kalangan masyarakat.

\section{DAFTAR PUSTAKA}

Asshiddiqie, Jimly, (2012), Hukum Tata Negara \& Pilar-pilar Demokrasi, Sinar Grafika : Jakarta, 2012.

Brownlie, Ian, (Penyunting.), (1993), Dokumen-Dokumen Pokok Mengenai Hak Asasi Manasia (Penerjemah: Beriansah), Jakarta, Universitas Indonesia (UI Press).

Direktorat Jenderal Pembelajaran dan Kemahasiswaan Kementerian Riset, Teknologi, dan Pendidikan Tinggi Republik Indonesia, Pendidikan Kewarganegaraan, 2016.

Ismatullah, Deddy dan Asep A. Sahid Gatara, (2007), Ilmu Negara dalam Multi Perspektif, Bandung: Pustaka Setia, 2007.

Kansil, C.S.T dan Christine S.T. Kansil, (2016) Ilmu Negara, Jakarta: PT. Pradya Paramita, 2001.

Kelsen, Hans, (2013) Teori Umum Tentang Hukum dan Negara (Penerjemah: Raisul Muttaqien dari Hans Kelsen, 1971, General Theory of Law and State, New York, Russel and Russel), Bandung, Cet. VIII, H1.

Moelyono, M, Anton, (1988), Kamus Besar Bahasa Indonesia, Jakarta, Departemen Pendidikan dan Kebudayaan Republik Indonesia, Hlm. 292; Bdk. Anonim, 2014, Kamus Besar Bahasa Indonesia Pusat Bahasa, Jakarta, PT. Gramedia Pustaka Utama, Edisi VII, Cet. IV.

Poerwadarminta, WJS, (2003), Kamus Umum Bahasa Indonesia, Jakarta, Balai Pustaka. Cet.XV.

Shorensen, Georg, (2003), Proses dan Prospek dalam Sebuah Dunia yang Sedang berubah, Ctk. Pertama, Yogyakarta: Pustaka Pelajar, 2003.

Yuliani. Andi, www. jdih.sukabumikab.go.id/v1/artikel/detail/5/hak-konstitusional-warganegara. Di unduh tanggal 21 April 2021. 